\title{
Mass Transfer in Osmotic Dehydration of Kiwiberry: Experimental and Mathematical Modelling Studies
}

\author{
Michał Bialik ${ }^{1}$, Artur Wiktor ${ }^{1}$, Piotr Latocha ${ }^{2}$ (D) and Ewa Gondek ${ }^{1, *}$ \\ 1 Faculty of Food Sciences, Department of Food Engineering and Process Management, \\ Warsaw University of Life Sciences, Nowoursynowska 159c, 02-776 Warsaw, Poland; \\ michal_bialik@sggw.pl (M.B.); artur_wiktor@sggw.pl (A.W.) \\ 2 Faculty of Horticulture, Biotechnology and Landscape Architecture, Department of Environmental \\ Protection, Warsaw University of Life Sciences, Nowoursynowska 159, 02-776 Warsaw, Poland; \\ piotr_latocha@sggw.pl \\ * Correspondence: ewa_gondek@sggw.pl; Tel.: +48-225-937-563
}

Received: 16 April 2018; Accepted: 14 May 2018; Published: 22 May 2018

\begin{abstract}
The aim of this study was to analyze the impact of osmotic solutions and temperature on the osmotic dehydration (OD) of two cultivars of kiwiberry. OD was carried out in sucrose, xylitol and maltitol solutions at $30^{\circ} \mathrm{C}$ and $50{ }^{\circ} \mathrm{C}$, respectively. The process of osmotic dehydration was described by the means of water loss (WL), solid gain (SG), weight reduction (WR), and water content changes. Moreover, dehydration was described by mathematical models often used in the literature. The highest WL, WR and SG values were observed for samples treated by xylitol and maltitol at $50{ }^{\circ} \mathrm{C}$. The statistical analysis of the mathematical modelling of the process showed that in most cases, the Peleg's equation exhibits better fitting for the experimental data.
\end{abstract}

Keywords: kiwiberry; osmotic dehydration; polyols; water loss; solid gain; mathematical modelling

\section{Introduction}

Food preservation is a process performed in order to slow down spoilage, loss of quality, and improve edibility and nutritional values. This usually involves inhibiting microorganisms growth as well as slowing down chemical reactions, such as oxidation of fats or discoloration caused by enzymatic browning [1]. Continuous interests placed on extending food shelf-life with improving food quality and safety, resulted in the development of "minimal" preservation techniques and adaptation of traditional methods, and the ways they can be combined with other technologies. Osmotic dehydration (OD) is one of the most popular traditional methods, since it can be easily combined with subsequent technological steps [2,3].

OD is a process in which migration of water through a semi permeable membrane, from a lower concentration of solute to a higher concentration, resulting in an equilibrium condition on both sides of membrane [1,4]. This process lowers both water content and water activity of a treated material. Properly applied, it improves retention of color, aroma, flavor and nutrients during further processing or storage [3]. Dehydration often precedes different preservation treatments, because when applied alone it is not sufficient to inhibit the growth of microbiota [2,5].

For OD, different types of agents are used. The most common agents are sugar, salt, and brine in the case of some vegetables [1]. Kinetics of the process depends on osmotic pressure, which is based on molarity and activity coefficient. With the same molarity, osmotic pressure depends only on the osmotic coefficient, which depends, in turn, on the temperature and molarity of a solute [6,7]. Although the goal of this method is to remove water from foods, in reality, it is a two-way mass transfer process [8]. Rate, effectiveness and outcome of this process depend on multiple factors, 
such as time, temperature, solute and its concentration, and type of dehydrated material [2,5]. Determination of proper parameters can result in obtaining foods that possess desired parameters and quality. As mentioned, OD often precedes further food processing steps, and in most cases, different methods of drying [9]. Public demand for less-caloric food induced the development of foods, replacing sugar with artificial sweeteners and polyols. The most popular osmotic agent is sugar, but it can strongly influence dehydrated products, especially if they often increase sugar content; for example, dried cranberries can contain up to $72.56 \%$ sugars [10]. Polyols have strong dehydrating capabilities and a sweetness similar to sucrose, and have low caloric values [11]. Osmotic pre-treatment of microwave-convective dried blueberries resulted in similar properties to those of untreated freeze-dried fruits [12].

Kiwi (Actinidia chinensis) is a popular fruit, which is known for its positive nutritional and health values, and is a unique enzyme, which promotes food digestion; that is, actinidine. A similar biochemical composition with the presence of the same enzyme can be found in kiwiberry (Actinidia arguta). Kiwiberry fruits are small and weigh between $6 \mathrm{~g}$ and $12 \mathrm{~g}$. They have smooth and hairless skin, so they can be eaten whole [13-15]. Kiwiberry is rich in vitamin C, minerals, phenolic acids and pigments, and has proven antioxidant and bacteriostatic properties, and they are widely known for their strong enzymatic activity [14]. Untreated fruits can be stored in cold stores up to six weeks, during which, bioactive compounds degrade and nutritional properties diminish. Not all fruits have optimum quality for direct consumption, and can be eaten only after some form of processing. Sustainable development requires establishing methods for managing variety of fruits, which is the reason why different methods of treatment and pre-treatment are still researched.

The aim of this study was to analyze the impact of different osmotic solutions and temperature on the OD of two cultivars of kiwiberry. According to the best knowledge of the authors, this is the first article that deals with this topic in the case of kiwiberry fruits.

\section{Results and Discussion}

\subsection{Weight Reduction}

Weight reduction (WR) denotes the net difference in weight between the initial weight of the sample and the weight of the dehydrated fruit based on the initial sample weight [16]. Figure 1 shows the WR of the samples during the OD of kiwiberry tissue. After $1 \mathrm{~h}$ of processing the 'Geneva' cultivar at $30^{\circ} \mathrm{C}$, the WR values were equal to $7.5 \%, 9.4 \%$ and $8.9 \%$ for the samples treated by sucrose, maltitol and xylitol, respectively (Figure 1a). In comparison, the values obtained for the dehydration of the 'Weiki' cultivar were equal to $5.5 \%, 2.6 \%$ and $5.7 \%$ for the samples treated by sucrose, maltitol and xylitol, respectively (Figure 1b). For the same process performed at $50{ }^{\circ} \mathrm{C}$, the values obtained for the 'Geneva' cultivar were equal to $12.8 \%, 11.0 \%$ and $14.7 \%$ for sucrose, maltitol and xylitol, respectively (Figure $1 \mathrm{~b}$ ). For the 'Weiki' cultivar, the WR values were $6.5 \%, 8.9 \%$ and $13.6 \%$ for the samples treated by sucrose, maltitol and xylitol, respectively (Figure 1d). The 'Geneva' cultivar seemed to be more susceptible to OD, so it had higher WR values, which probably resulted from the thinner skin of the 'Geneva' fruits, whereas the 'Weiki' fruits have a higher endurance against environmental factors. In the case of this experiment, their resistance against mass transfer, which was represented by lower WR values, was diminished after the temperature was raised. The $50{ }^{\circ} \mathrm{C}$ tested samples showed similar and comparable results despite using different osmotic solutions (Figure 1c,d). After $180 \mathrm{~min}$ of the process carried out at $30^{\circ} \mathrm{C}$, the 'Geneva' kiwiberry fruits reached the WR values of $7.0 \%$ and $11.3 \%$ for sucrose and xylitol, respectively (Figure 1a). The same solutions at $50{ }^{\circ} \mathrm{C}$ provided WR values of $20 \%$ to $22 \%$ for sucrose and xylitol, respectively (Figure $1 \mathrm{~b}$ ). For the 'Weiki' cultivar, after $60 \mathrm{~min}$ of OD at $30{ }^{\circ} \mathrm{C}$, WR values were $4.7 \%$ for sucrose and $8.7 \%$ for xylitol, respectively (Figure 1c). Applying high temperature resulted in a maximum WR value of $17.0 \%$ for maltitol and $16.8 \%$ for xylitol, respectively (Figure 1d). 


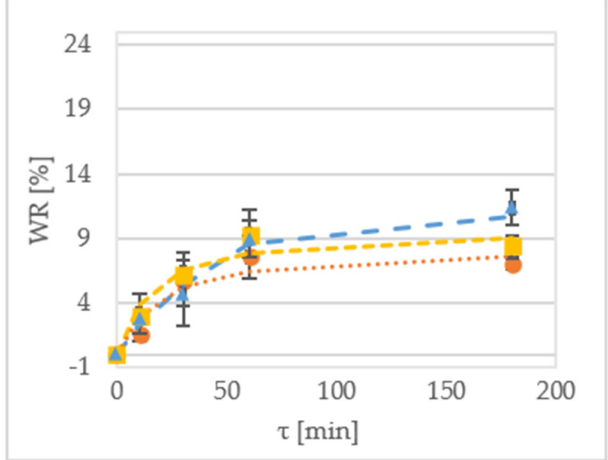

(a)

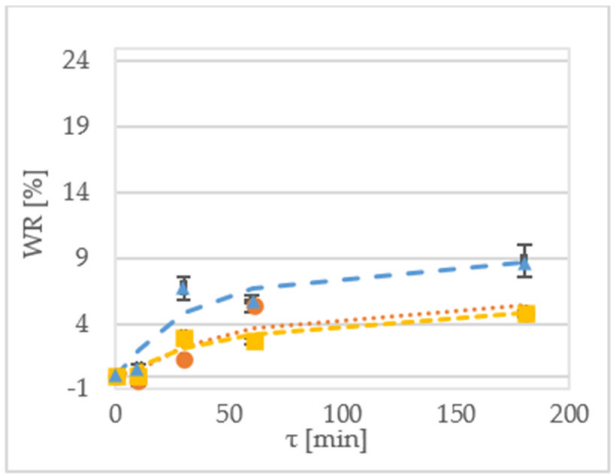

(c)

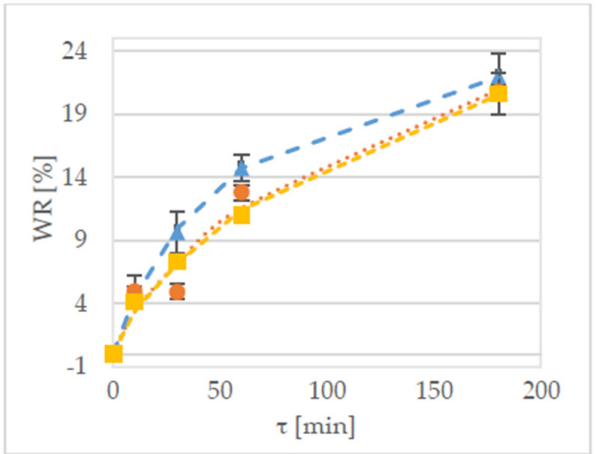

(b)

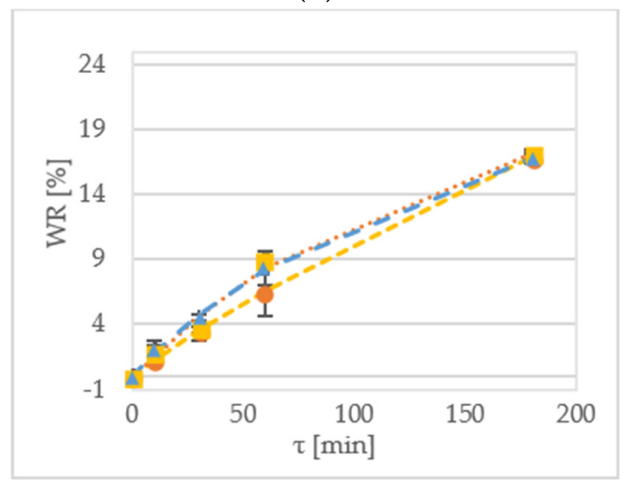

(d)

Figure 1. WR kinetics of the 'Geneva' cultivar dehydrated at (a) $30{ }^{\circ} \mathrm{C}$; and (b) $50{ }^{\circ} \mathrm{C}$ in xylitol ( $\Delta$-triangle), maltitol ( $\mathbf{\square}$-square) and sucrose (-circle). WR kinetics of the 'Weiki' cultivar dehydrated at (c) $30{ }^{\circ} \mathrm{C}$; and (d) $50{ }^{\circ} \mathrm{C}$ in xylitol ( - -triangle), maltitol ( $\boldsymbol{\square}$-square) and sucrose (- circle). Dotted lines represent values obtained from the mathematical modelling.

During the experiment, there was a noticeable slowing down of WR kinetics. Water leaving the tissue lowered osmotic pressure and influenced further processing. Occurrence of this phenomena could be diminished by increasing the ratio of solution to sample mass, which was used in the experiment performed by Kowalski and Mierzwa [3] and Tiroutchelvame et al. [17]. In the study by Arballo et al. [18], researchers suggested that the optimum value for dehydrated cubes of fruits (pumpkin, kiwi, pear) resides between $112 \mathrm{~min}$ and $240 \mathrm{~min}$ of processing. For the kiwi cubes [18], established by Arballo et al., the WR value equal to $27.8 \%$ was obtained when they were in $60 \%$ solute of sucrose for $145 \mathrm{~min}$ at $30{ }^{\circ} \mathrm{C}$. Comparable observations can be made for kiwiberry halves at $30^{\circ} \mathrm{C}$. In addition, temperature strongly influenced obtained values, which was also confirmed by Alam et al. [19], Yadav et al. [20] and Cichowska et al. [21]. During OD of anola slices researched by Alam et al. [19] at temperatures between $30^{\circ} \mathrm{C}$ and $60^{\circ} \mathrm{C}$, the optimum temperature was established at $51{ }^{\circ} \mathrm{C}$.

In this experiment, xylitol was determined as the most effective osmotic reagent for reaching high WR values (Figure 1). High efficiency of this polyol was confirmed by Mendonça et al. $[9,18]$ and Cichowska et al. [21]. Both authors agree that it is the result of xylitol's low molecular weight. It is also worth noticing that all the investigated parameters of the OD had significant impacts on the WR values (Table 1). Statistical analysis has also shown interactions between the tested variables (Table 2); a significant for interaction between temperature-time-solution $(p<0.05)$ and a significant for temperature-time $(p<0.01)$ were identified. According to some researchers, WR is mostly influenced by the concentration of the osmotic solution and the temperature [22]. The experiment performed on the kiwifruit slices by Cao et al. [23], showed that the temperature of the process lessened the influence of the other factors or their combinations. 
Table 1. The influence of osmotic pre-treatment in different solutions, and time on WR.

\begin{tabular}{|c|c|c|c|c|c|}
\hline \multicolumn{2}{|c|}{ Factor } & \multirow{2}{*}{$\begin{array}{l}p \text {-Value } \\
<0.001 *\end{array}$} & \multirow{2}{*}{$\begin{array}{c}\text { Contrast } \\
\text { Geneva-Weiki }\end{array}$} & \multirow{2}{*}{$\begin{array}{c}\text { +/- Limits } \\
0.006\end{array}$} & \multirow{2}{*}{$\begin{array}{c}\text { Difference } \\
0.034^{*}\end{array}$} \\
\hline Cultivar & $\begin{array}{l}\text { Geneva }^{a} \\
\text { Weiki }^{b}\end{array}$ & & & & \\
\hline Temperature & $\begin{array}{l}30^{\circ} \mathrm{C}^{\mathrm{a}} \\
50^{\circ} \mathrm{C}^{\mathrm{b}}\end{array}$ & $<0.001 *$ & $30^{\circ} \mathrm{C}-50^{\circ} \mathrm{C}$ & -0.044 & -0.005 * \\
\hline Time & $\begin{array}{c}10 \min ^{\mathrm{a}} \\
30 \min ^{\mathrm{b}} \\
1 \mathrm{~h}^{\mathrm{c}} \\
3 \mathrm{~h}^{\mathrm{d}}\end{array}$ & $<0.001 *$ & $\begin{array}{l}10 \mathrm{~min}-60 \mathrm{~min} \\
10 \mathrm{~min}-30 \mathrm{~min} \\
10 \mathrm{~min}-180 \mathrm{~min} \\
60 \mathrm{~min}-30 \mathrm{~min} \\
60 \mathrm{~min}-180 \mathrm{~min} \\
30 \mathrm{~min}-180 \mathrm{~min}\end{array}$ & $\begin{array}{l}0.008 \\
0.008 \\
0.008 \\
0.008 \\
0.008 \\
0.008\end{array}$ & $\begin{array}{l}-0.062 * \\
-0.028^{*} \\
-0.112 * \\
0.033^{*} \\
-0.050 * \\
-0.084^{*}\end{array}$ \\
\hline $\begin{array}{l}\text { Osmotic } \\
\text { solution }\end{array}$ & $\begin{array}{l}\text { Sucrose }^{\mathrm{a}} \\
\text { Maltitol }^{\mathrm{a}} \\
\text { Xylitol }^{\mathrm{b}}\end{array}$ & $<0.001 *$ & $\begin{array}{l}\text { Xylitol-Maltitol } \\
\text { Xylitol-Sucrose } \\
\text { Maltitol-Sucrose }\end{array}$ & $\begin{array}{l}0.007 \\
0.007 \\
0.008\end{array}$ & $\begin{array}{c}0.014 * \\
0.019 * \\
0.004\end{array}$ \\
\hline
\end{tabular}

Note: Means within columns, sharing the same superscript, are not significantly different from each other (Tukey's HSD, $p<0.05) .{ }^{*}$ denotes a statistically significant difference.

Table 2. Interactions between tested variables for WR, WL and SG expressed by $p$-values.

\begin{tabular}{lcccccccccc}
\hline & \multicolumn{10}{c}{ Interaction } \\
\cline { 2 - 11 } & $\mathbf{A B}$ & $\mathbf{A C}$ & AD & BC & BD & CD & ABC & ABD & ACD & BCD \\
\hline WR & 0.148 & 0.059 & 0.848 & $<0.001^{*}$ & 0.311 & 0.098 & 0.938 & 0.026 & 0.465 & $0.022^{*}$ \\
WL & 0.335 & $0.009^{*}$ & 0.304 & $<0.001^{*}$ & 0.210 & $<0.001^{*}$ & 0.492 & 0.339 & 0.074 & $0.002^{*}$ \\
SG & 0.554 & $0.007^{*}$ & $0.019^{*}$ & $<0.001^{*}$ & 0.388 & $<0.001^{*}$ & 0.067 & $0.005^{*}$ & 0.1898 & 0.452 \\
\hline \multicolumn{10}{c}{ A—cultivar, B-temperature, C-time, D—osmotic solution. }
\end{tabular}

One of the aims of this study was to determine the best fitting model for OD kinetics. Two popular equations were used and modelled, i.e., Peleg's [24] and Ade-Omowaye et al. [25]. The results of the statistical evaluation of experimental regression analysis for the WR are presented in Table 3. $C R V$ values lower than $20 \%$ indicate usefulness of the tested equation for the prediction of the process [26]. Mathematical modelling has shown higher usefulness of the Peleg's model for the WR prediction. It was the only model that could calculate the expected values for process at $30{ }^{\circ} \mathrm{C}$, although the resulting $C R V$ values were too high for practical use. On the other hand, fitting values for $50{ }^{\circ} \mathrm{C}$ have given high $R^{2}$ values, and low CRV, RMSE and $\chi^{2}$ values (Table 3). The Peleg's equation has two independent variables representing initial mass transfer rate $\left(K_{1}\right)$ and equilibrium moisture content $\left(K_{2}\right)$. The $K_{1}$ and $K_{2}$ values for the $50{ }^{\circ} \mathrm{C}$ process indicated both high transfer and water removal rates (Figure $2 a, c)$. The $K_{1}$ values decreased with the increase of the temperature. There was no visible trend for the $K_{2}$ values. The usefulness of the Peleg's model was also confirmed by Arballo et al. [18] when researchers were using this model for predicting the OD of different fruits.

\subsection{Water Loss}

Water loss $(\mathrm{WL})$ is a parameter that indicates amount of water removed during pre-treatment in relation to initial sample mass [16]. Figure 1 shows water loss of samples during the OD of kiwiberry tissue. In most cases, the WL value for samples processed with xylitol, was higher when compared to the other osmotic solutions. For instance, after $10 \mathrm{~min}$ of immersion, the WR value at $30^{\circ} \mathrm{C}$ of the 'Geneva' cultivar was $0.14 \mathrm{~g} / \mathrm{g}$ initial dry matter (i.d.m.) and $0.25 \mathrm{~g} / \mathrm{g}$ i.d.m. for sucrose and maltitol, respectively (Figure 2a). In turn, for the 'Weiki' cultivar, the WL reached values of $0.33 \mathrm{~g} / \mathrm{g}$ i.d.m. for sucrose and $0.37 \mathrm{~g} / \mathrm{g}$ i.d.m. for xylitol, respectively (Figure 2c). 


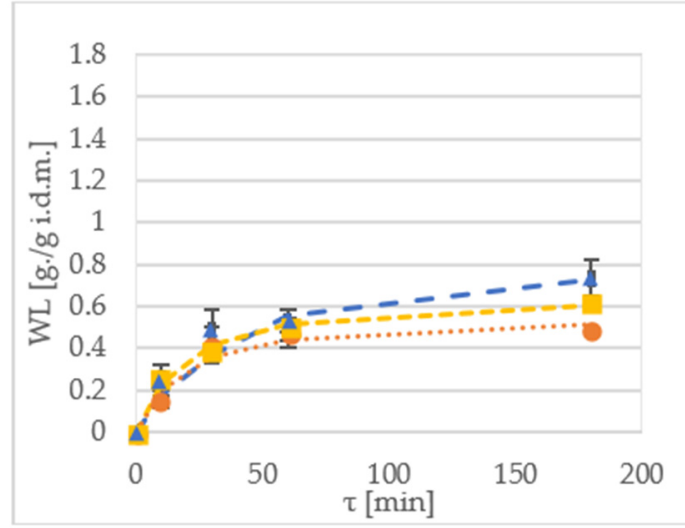

(a)

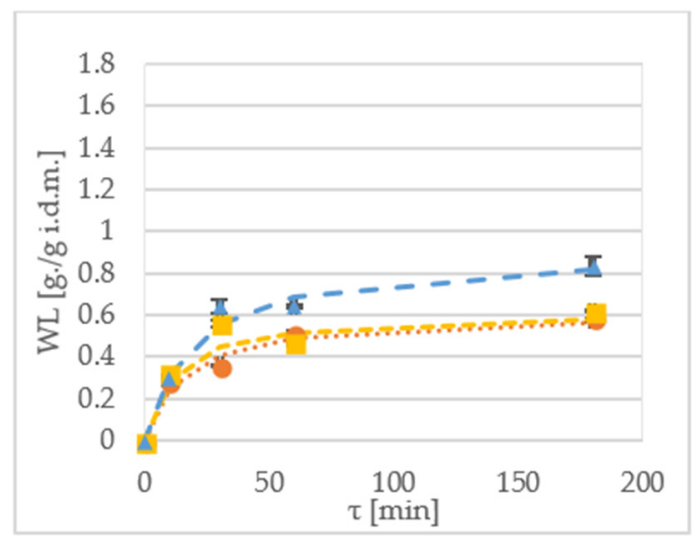

(c)

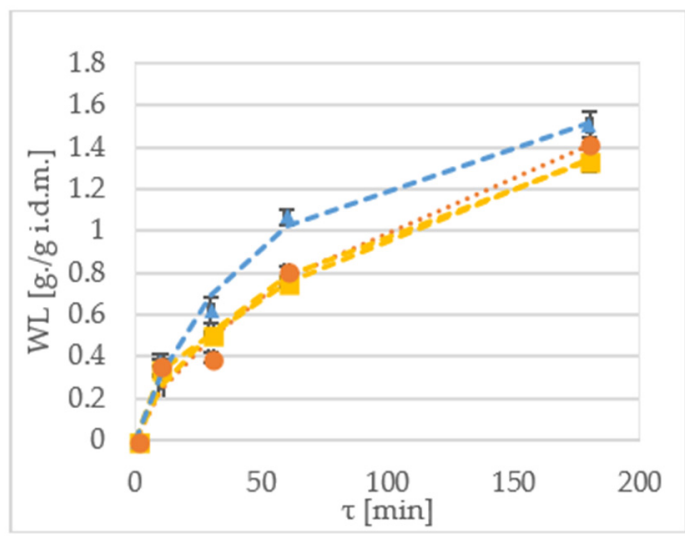

(b)

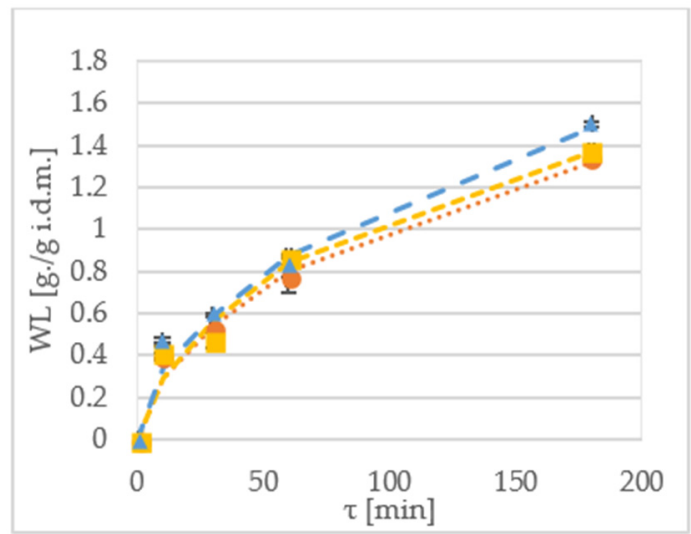

(d)

Figure 2. WL kinetics of the 'Geneva' cultivar dehydrated at (a) $30^{\circ} \mathrm{C}$; and (b) $50{ }^{\circ} \mathrm{C}$ in xylitol ( $\Delta$ -triangle), maltitol ( - square) and sucrose (-circle). WL kinetics of the 'Weiki' cultivar dehydrated

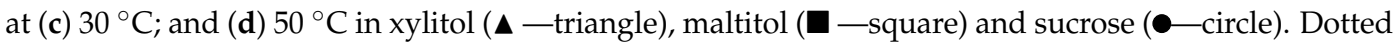
lines represent values obtained from the mathematical modelling.

After 60 min of the process, the highest WL values were obtained for the samples dehydrated at $50{ }^{\circ} \mathrm{C}$, reaching values between $1.06 \mathrm{~g} / \mathrm{g}$ i.d.m. for the 'Geneva' cultivar (Figure $2 \mathrm{~b}$ ), and $0.87 \mathrm{~g} / \mathrm{g}$ i.d.m. for the 'Weiki' cultivar (Figure 2d), both dehydrated in xylitol. In the case of the $30{ }^{\circ} \mathrm{C}$ treatment in xylitol, the highest WL values were obtained equal to $0.53 \mathrm{~g} / \mathrm{g}$ i.d.m. for the 'Geneva' cultivar (Figure 2a) and $0.64 \mathrm{~g} / \mathrm{g}$ i.d.m. for the 'Weiki' cultivar (Figure 2c). Prolonging the process up to $180 \mathrm{~min}$ allowed further water removal. During this experiment, the highest WL values for both the 'Geneva' and 'Weiki' cultivars, were obtained from the samples processed with xylitol after $180 \mathrm{~min}$ of the OD at $50{ }^{\circ} \mathrm{C}$, which reached up to $1.5 \mathrm{~g} / \mathrm{g}$ i.d.m. (Figure $2 \mathrm{~b}, \mathrm{~d}$ ). The lowest experimental values of the WL were achieved for materials kept at $30{ }^{\circ} \mathrm{C}$ in sucrose, which were $0.48 \mathrm{~g} / \mathrm{g}$ i.d.m. and $0.57 \mathrm{~g} / \mathrm{g}$ i.d.m. for the 'Geneva' and 'Weiki' cultivars, respectively (Figure 2a,c).

The established WL values suggest that $60 \mathrm{~min}$ OD of kiwiberry at $30{ }^{\circ} \mathrm{C}$ allows to achieve results similar to $30 \mathrm{~min}$ immersion at $50{ }^{\circ} \mathrm{C}$. As expected, the maximum WL values were reached in the case of the longest processing time $(180 \mathrm{~min})$ performed at the highest temperature $\left(50{ }^{\circ} \mathrm{C}\right)$. Such high temperature, although it is beneficial for OD kinetics, can influence biochemical properties of the material [27]. Statistical analysis showed significant differences in applied temperatures, osmotic solutions and process durations. There was no significant difference between the tested cultivars (Table 4$)$. There were a few significant $(p<0.05)$ interactions between the tested variables (Table 2) for cultivar-time, temperature-time-solution, and very strong interaction $(p<0.01)$ for variables of temperature-time and time-solution. 
Table 3. Values of $R M S E, \chi^{2}, R^{2}$ and $C R V$ of best fitting mathematical model of WR.

\begin{tabular}{|c|c|c|c|c|c|c|c|c|c|c|}
\hline Cultivar & Temperature & Solution & Model & $\bar{K}$ & $K_{2}$ & $K_{\mathrm{m}}$ & RMSE & $\chi^{2}$ & $C R V(\%)$ & $R^{2}$ \\
\hline \multirow{12}{*}{ Geneva } & \multirow{6}{*}{$30{ }^{\circ} \mathrm{C}$} & \multirow{2}{*}{ sucrose } & Ade-Omowaye & - & - & 0.006 & 0.019 & 0.001 & 40.89 & 0.507 \\
\hline & & & Peleg & 11.171 & -0.006 & - & 0.012 & 0.001 & 25.11 & 0.814 \\
\hline & & \multirow{2}{*}{ maltitol } & Ade-Omowaye & - & - & - & - & - & - & - \\
\hline & & & Peleg & 9.839 & -0.004 & - & 0.012 & 0.001 & 20.30 & 0.851 \\
\hline & & \multirow{2}{*}{ xylitol } & Ade-Omowaye & - & - & - & - & - & - & - \\
\hline & & & Peleg & 8.468 & 0.003 & - & 0.017 & 0.001 & 21.20 & 0.896 \\
\hline & \multirow{6}{*}{$50{ }^{\circ} \mathrm{C}$} & \multirow{2}{*}{ sucrose } & Ade-Omowaye & - & - & - & - & - & - & - \\
\hline & & & Peleg & 2.780 & 0.009 & - & 0.015 & 0.000 & 17.35 & 0.950 \\
\hline & & \multirow{2}{*}{ maltitol } & Ade-Omowaye & - & - & - & - & - & - & - \\
\hline & & & Peleg & 2.881 & 0.011 & - & 0.008 & 0.000 & 9.10 & 0.985 \\
\hline & & \multirow{2}{*}{ xylitol } & Ade-Omowaye & - & - & - & - & - & - & - \\
\hline & & & Peleg & 3.468 & 0.000 & - & 0.009 & 0.000 & 8.82 & 0.982 \\
\hline \multirow{12}{*}{ Weiki } & \multirow{6}{*}{$30{ }^{\circ} \mathrm{C}$} & \multirow{2}{*}{ sucrose } & Ade-Omowaye & - & - & - & - & - & - & - \\
\hline & & & Peleg & 12.525 & -0.009 & - & 0.011 & 0.000 & 49.16 & 0.763 \\
\hline & & \multirow{2}{*}{ maltitol } & Ade-Omowaye & - & - & - & - & - & - & - \\
\hline & & & Peleg & 14.953 & -0.004 & - & 0.006 & 0.000 & 27.75 & 0.886 \\
\hline & & \multirow{2}{*}{ xylitol } & Ade-Omowaye & - & - & - & - & - & - & - \\
\hline & & & Peleg & 9.001 & -0.008 & - & 0.013 & 0.000 & 29.75 & 0.838 \\
\hline & \multirow{6}{*}{$50{ }^{\circ} \mathrm{C}$} & \multirow{2}{*}{ sucrose } & Ade-Omowaye & - & - & - & - & - & - & - \\
\hline & & & Peleg & 1.193 & 0.001 & - & 0.006 & 0.000 & 10.73 & 0.989 \\
\hline & & \multirow{2}{*}{ maltitol } & Ade-Omowaye & - & - & - & - & - & - & - \\
\hline & & & Peleg & 2.776 & -0.002 & - & 0.007 & 0.000 & 10.75 & 0.986 \\
\hline & & \multirow{2}{*}{ xylitol } & Ade-Omowaye & - & - & - & - & - & - & - \\
\hline & & & Peleg & 2.834 & 0.002 & - & 0.004 & 0.000 & 7.26 & 0.993 \\
\hline
\end{tabular}

Table 4. The influence of osmotic pre-treatment in different solutions, and time on WL (g/g i.d.m.).

\begin{tabular}{|c|c|c|c|c|c|}
\hline \multicolumn{2}{|c|}{ Factor } & $p$-Value & Contrast & $+/-$ Limits & Difference \\
\hline Cultivar & $\begin{array}{l}\text { Geneva }^{\mathrm{a}} \\
\text { Weiki }^{\mathrm{a}}\end{array}$ & 0.187 & Geneva-Weiki & -0.018 & 0.027 \\
\hline Temperature & $\begin{array}{l}30^{\circ} \mathrm{C}^{\mathrm{a}} \\
50^{\circ} \mathrm{C}^{\mathrm{b}}\end{array}$ & $<0.001 *$ & $30^{\circ} \mathrm{C}-50^{\circ} \mathrm{C}$ & 0.027 & $-0.312 *$ \\
\hline Time & $\begin{array}{c}10 \min ^{\mathrm{a}} \\
30 \min ^{\mathrm{b}} \\
1 \mathrm{~h}^{\mathrm{c}} \\
3 \mathrm{~h}^{\mathrm{d}}\end{array}$ & $<0.001$ * & $\begin{array}{l}10 \mathrm{~min}-60 \mathrm{~min} \\
10 \mathrm{~min}-30 \mathrm{~min} \\
10 \mathrm{~min}-180 \mathrm{~min} \\
60 \mathrm{~min}-30 \mathrm{~min} \\
60 \mathrm{~min}-180 \mathrm{~min} \\
30 \mathrm{~min}-180 \mathrm{~min}\end{array}$ & $\begin{array}{l}0.039 \\
0.039 \\
0.039 \\
0.039 \\
0.039 \\
0.039\end{array}$ & $\begin{array}{l}-0.362 * \\
-0.147 * \\
-0.733 * \\
0.215^{*} \\
-0.371 * \\
-0.586 *\end{array}$ \\
\hline Osmotic solution & $\begin{array}{l}\text { Sucrose }^{\mathrm{a}} \\
\text { Maltitol }^{\mathrm{a}} \\
\text { Xylitol }^{\mathrm{b}}\end{array}$ & $<0.001$ * & $\begin{array}{l}\text { Xylitol-Maltitol } \\
\text { Xylitol-Sucrose } \\
\text { Maltitol-Sucrose }\end{array}$ & $\begin{array}{l}0.034 \\
0.034 \\
0.033\end{array}$ & $\begin{array}{c}0.122 * \\
0.151 * \\
0.028\end{array}$ \\
\hline
\end{tabular}

Note: Means within columns, sharing the same superscript, are not significantly different from each other (Tukey's HSD, $p<0.05) .{ }^{*}$ denotes a statistically significant difference.

Difference in osmotic pressure between solution and tissue is the driving force of the dehydration. Calculated ideal osmotic pressures, based on the equation given by Held et al. [7] with the used solutes at $30^{\circ} \mathrm{C}$, were $4418.13 \mathrm{kPa}, 4392.33 \mathrm{kPa}$ and $9939.70 \mathrm{kPa}$ for sucrose, maltitol and xylitol, respectively. At $50{ }^{\circ} \mathrm{C}$, the established osmotic pressures were $4709.61 \mathrm{kPa}, 4682.12 \mathrm{kPa}$ and $10595.46 \mathrm{kPa}$ for sucrose, maltitol and xylitol, respectively. During the process, water migrates to the solution, which lowers osmotic agents density and as a result, slows down OD [1,28]. High initial WL ratio after the first $2 \mathrm{~h}$ of OD, was also observed by Panagiotou et al. [29], who were dehydrating apples, bananas and kiwis using $40 \%$ sucrose at $40{ }^{\circ} \mathrm{C}$. Similar observations were also made by Arballo et al. [18], where scientists 
dehydrated pumpkins, kiwis and pears. They have noticed that the time of the process influences the outcome of the dehydration during the first $4 \mathrm{~h}$ of the process. In this experiment, similar observations can be made for samples immersed in samples at $30^{\circ} \mathrm{C}$. For kiwiberry treated at $50{ }^{\circ} \mathrm{C}$, it should be taken into consideration that lengthening the process up to at least $4 \mathrm{~h}$ establishes plateau values. With the increased temperature, the viscosity of the osmotic reagent decreases, and as a result, the mass transfer improves [20]. The influence of temperature on OD was confirmed by Ciurzyńska et al. [30], in the OD of apples at temperatures of $40^{\circ} \mathrm{C}$ and $60^{\circ} \mathrm{C}$. In this experiment, xylitol was determined as the most effective osmotic reagent (Figure 2). It is also worth noticing that difference in dehydration effectiveness between sucrose and maltitol turned out to be statistically insignificant (Table 4). This was caused by the molecular weight of the solutes used. Lower molecular weight yields higher osmotic pressure (maltitol $344.31 \mathrm{~g} / \mathrm{mol}$, sucrose $342.3 \mathrm{~g} / \mathrm{mol}$ and xylitol $152.15 \mathrm{~g} / \mathrm{mol}$ ).

The Peleg's modelling of the WL was effective in almost all of the tested combinations of the used variables (Table 5). Goodness of fit for this model has given high $R^{2}$ values, and low CRV, RMSE and $\chi^{2}$, which is expected for applicable models. High goodness of fit of this model for the OD was also reported by Yadav and Singh [1] and Cichowska et al. [21].

Table 5. Values of RMSE, $\chi^{2}, R^{2}$ and CRV of best fitting mathematical model of WL.

\begin{tabular}{|c|c|c|c|c|c|c|c|c|c|c|}
\hline Cultivar & Temperature & Solution & Model & $K_{1}$ & $K_{2}$ & $K_{\omega}$ & RMSE & $x^{2}$ & $C R V(\%)$ & $R^{2}$ \\
\hline \multirow{12}{*}{ Geneva } & \multirow{6}{*}{$30{ }^{\circ} \mathrm{C}$} & \multirow{2}{*}{ sucrose } & Ade-Omowaye & - & - & 0.043 & 0.119 & 0.016 & 35.91 & 0.538 \\
\hline & & & Peleg & 1.711 & -0.028 & - & 0.056 & 0.003 & 16.91 & 0.897 \\
\hline & & \multirow{2}{*}{ maltitol } & Ade-Omowaye & - & - & 0.052 & 0.098 & 0.010 & 25.01 & 0.735 \\
\hline & & & Peleg & 1.520 & 0.012 & - & 0.037 & 0.001 & 9.51 & 0.961 \\
\hline & & \multirow{2}{*}{ xylitol } & Ade-Omowaye & - & - & 0.079 & 0.081 & 0.008 & 17.87 & 0.948 \\
\hline & & & Peleg & 1.448 & 0.013 & - & 0.082 & 0.009 & 11.83 & 0.959 \\
\hline & \multirow{6}{*}{$50{ }^{\circ} \mathrm{C}$} & \multirow{2}{*}{ sucrose } & Ade-Omowaye & - & - & 0.101 & 0.079 & 0.008 & 13.49 & 0.967 \\
\hline & & & Peleg & 0.402 & 0.100 & - & 0.077 & 0.007 & 13.06 & 0.969 \\
\hline & & \multirow{2}{*}{ maltitol } & Ade-Omowaye & - & - & 0.099 & 0.029 & 0.001 & 5.02 & 0.995 \\
\hline & & & Peleg & 0.484 & 0.102 & - & 0.054 & 0.004 & 9.22 & 0.982 \\
\hline & & \multirow{2}{*}{ xylitol } & Ade-Omowaye & - & - & 0.118 & 0.082 & 0.008 & 11.64 & 0.969 \\
\hline & & & Peleg & 0.507 & 0.036 & - & 0.056 & 0.004 & 7.93 & 0.986 \\
\hline \multirow{12}{*}{ Weiki } & \multirow{6}{*}{$30{ }^{\circ} \mathrm{C}$} & \multirow{2}{*}{ sucrose } & Ade-Omowaye & - & - & 0.052 & 0.095 & 0.011 & 27.75 & 0.663 \\
\hline & & & Peleg & 1.681 & 0.016 & - & 0.031 & 0.001 & 9.04 & 0.964 \\
\hline & & \multirow{2}{*}{ maltitol } & Ade-Omowaye & - & - & 0.055 & 0.104 & 0.013 & 28.53 & 0.618 \\
\hline & & & Peleg & 1.645 & 0.010 & - & 0.034 & 0.001 & 9.32 & 0.959 \\
\hline & & \multirow{2}{*}{ xylitol } & Ade-Omowaye & - & - & 0.073 & 0.120 & 0.018 & 25.45 & 0.761 \\
\hline & & & Peleg & 1.104 & -0.002 & - & 0.035 & 0.001 & 7.35 & 0.980 \\
\hline & \multirow{6}{*}{$50^{\circ} \mathrm{C}$} & \multirow{2}{*}{ sucrose } & Ade-Omowaye & - & - & 0.099 & 0.045 & 0.002 & 7.57 & 0.986 \\
\hline & & & Peleg & 0.517 & 0.135 & - & 0.070 & 0.006 & 11.78 & 0.967 \\
\hline & & \multirow{2}{*}{ maltitol } & Ade-Omowaye & - & - & 0.103 & 0.067 & 0.005 & 10.81 & 0.973 \\
\hline & & & Peleg & 0.510 & 0.113 & - & 0.079 & 0.007 & 12.78 & 0.963 \\
\hline & & \multirow{2}{*}{ xylitol } & Ade-Omowaye & - & - & 0.111 & 0.060 & 0.004 & 9.03 & 0.980 \\
\hline & & & Peleg & 0.426 & 0.186 & - & 0.089 & 0.010 & 13.36 & 0.957 \\
\hline
\end{tabular}

"-" denotes values which cannot be calculated using this prediction model.

The Peleg's equation has two independent variables, where $K_{1}$ represents initial mass transfer rate and $K_{2}$ describes equilibrium moisture content. As it was aforementioned, low $K_{1}$ and $K_{2}$ values indicate both high mass transfer and high water removal rates [21,31]. Measured WL values suggest lower effectiveness of sucrose and maltitol, in comparison to xylitol carried out at $30{ }^{\circ} \mathrm{C}$ (Figure 1a,c). Statistical analysis has shown that these two osmotic agents belong to the same homogeneous group (Table 3). This could be explained by similar and high molecular weight of these solutions; such observations were also reported by Mendonça et al. [11]. Molecular weight could have also influenced the $K_{1}$ values for the $\mathrm{OD}$ at $30^{\circ} \mathrm{C}$; such phenomena were also reported by other researchers [28]. In addition, it could be explained by similar osmotic coefficient values, and should be further explored in the future experiments. 


\subsection{Solid Gain}

Solid gain (SG) is a parameter which indicates amount of soluble solids that are incorporated into the sample during dehydration [16]. Figure 3 shows SG of samples during the OD of kiwiberry halves. After $60 \mathrm{~min}$ OD of the 'Geneva' cultivar at $30{ }^{\circ} \mathrm{C}$, the SG value were $0.08 \mathrm{~g} / \mathrm{g}$ i.d.m., $0.07 \mathrm{~g} / \mathrm{g}$ i.d.m. and $0.09 \mathrm{~g} / \mathrm{g}$ i.d.m. for samples treated by sucrose, maltitol and xylitol, respectively (Figure 3a). The 'Weiki' samples were more prone to display higher SG values, which were 0.31 g/g i.d.m., $0.32 \mathrm{~g} / \mathrm{g}$ i.d.m. and $0.34 \mathrm{~g} / \mathrm{g}$ i.d.m. for sucrose, maltitol and xylitol, respectively (Figure $3 \mathrm{c}$ ). When the process was performed at $50^{\circ} \mathrm{C}$, the SG values obtained for the 'Geneva' cultivar were $0.14 \mathrm{~g} / \mathrm{g}$ i.d.m., $0.19 \mathrm{~g} / \mathrm{g}$ i.d.m. and $0.3 \mathrm{~g} / \mathrm{g}$ i.d.m. for sucrose, maltitol and xylitol, respectively (Figure $3 \mathrm{~b}$ ). For the 'Weiki' cultivar treated at $50{ }^{\circ} \mathrm{C}$, the SG values were $0.43 \mathrm{~g} / \mathrm{g}$ i.d.m., $0.41 \mathrm{~g} / \mathrm{g}$ i.d.m. and $0.31 \mathrm{~g} / \mathrm{g}$ i.d.m. for sucrose, maltitol and xylitol, respectively (Figure 3d). In both temperatures, the 'Geneva' cultivar seemed to be more efficient in the SG. As it was mentioned earlier, the dehydration at $50{ }^{\circ} \mathrm{C}$ displays the similar effectiveness despite using different osmotic solutions. On the other hand, the $30{ }^{\circ} \mathrm{C}$ processing shows larger SG differences between the used solutes. Comparable results for the $60 \mathrm{~min}$ dehydration at $50{ }^{\circ} \mathrm{C}$ were achieved after $180 \mathrm{~min}$ of the $\mathrm{OD}$ at $30{ }^{\circ} \mathrm{C}$. Similar observations were also made for shorter processing time. For instance, after $10 \mathrm{~min}$ of the immersion at $30^{\circ} \mathrm{C}$, the SG values were similar to the $60 \mathrm{~min}$ process at $30^{\circ} \mathrm{C}$.

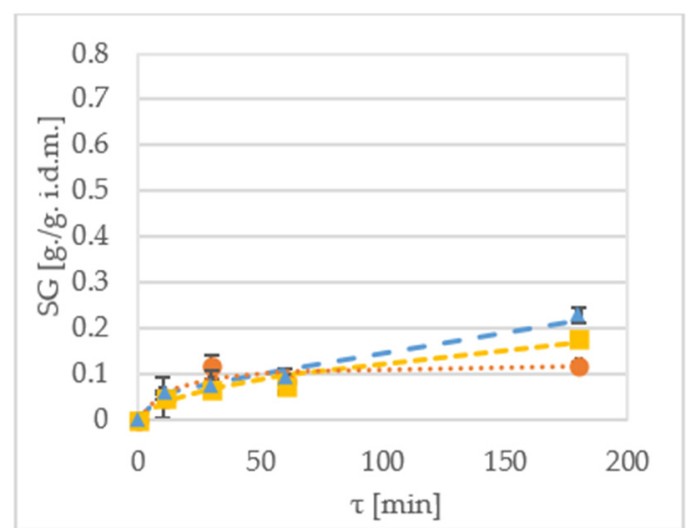

(a)

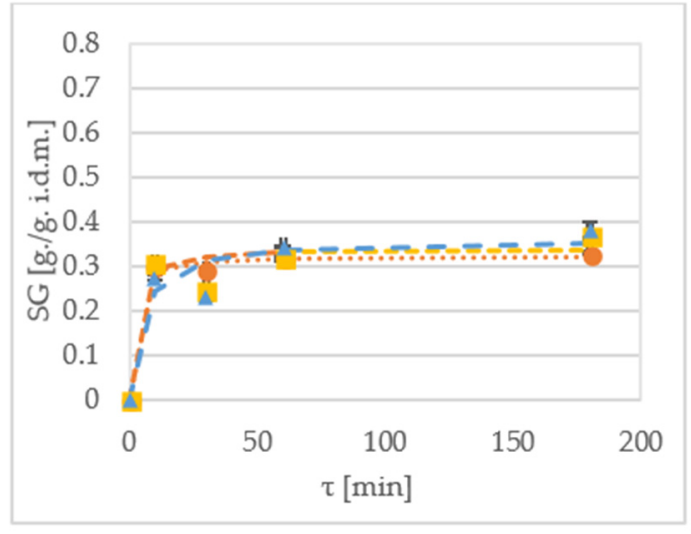

(c)

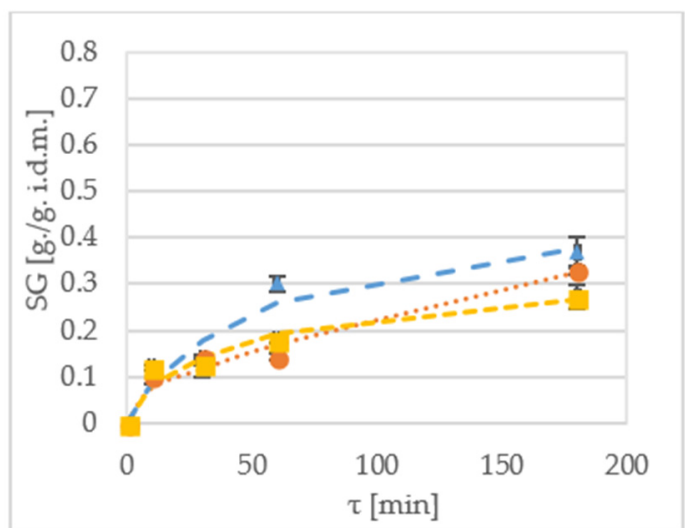

(b)

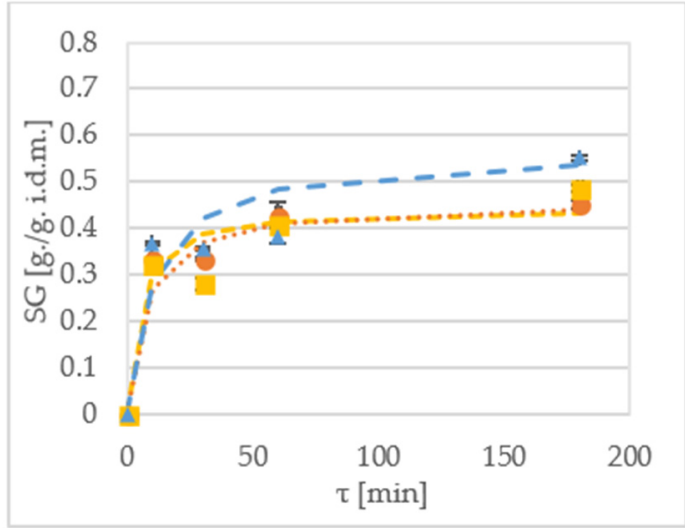

(d)

Figure 3. SG kinetics of the 'Geneva' cultivar dehydrated at (a) $30^{\circ} \mathrm{C}$; and (b) $50^{\circ} \mathrm{C}$ in xylitol ( $\mathbf{\Delta}$-triangle), maltitol (ם-square) and sucrose (- circle). SG kinetics of. the 'Weiki' cultivar dehydrated at (c) $30^{\circ} \mathrm{C}$

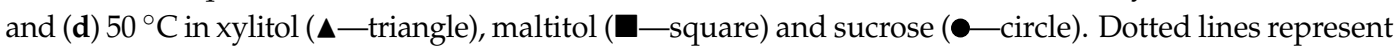
values obtained from the mathematical modelling. 
During the experiment performed by Chiu et al. [32] and Lee et al. [33], researchers noticed that SG values are strongly influenced by temperature during the OD of Terung Asam and red algae, respectively. This was also the case during kiwiberry dehydration. The SG values after 180 min dehydration were $25-50 \%$ higher when the temperature was raised by $20^{\circ} \mathrm{C}$. According to Lazarides et al. [34], higher temperature promotes faster water loss by plasticizing of cell membranes, increasing water diffusion and lowering viscosity of the osmotic medium. The difference in the SG ratios between the tested cultivars can be explained by the difference in strengths of cell membranes. SG is strongly influenced by ratios of solute to mass [17,32]. Although some researchers suggest the increase of this ratio [3], results of different studies focused on effectiveness and quality of final product [17] claim that a ratio of 5:1 is the optimized value from industrial and scientific perspectives. In this experiment, a ratio of 4:1 was used, which is a well-established experimental standard. Statistical analysis had shown that all the tested parameters had a statistically significant impact on the SG. However, it is worth mentioning that there was no statistical difference between $10 \mathrm{~min}$ and $30 \mathrm{~min}$ dehydration and between maltitol and sucrose (Table 6).

Table 6. The influence of osmotic pre-treatment in different solutions, and time on SG [g/g i.d.m.].

\begin{tabular}{|c|c|c|c|c|c|}
\hline \multicolumn{2}{|l|}{ Factor } & $p$-Value & Contrast & $+/-$ Limits & Difference \\
\hline Cultivar & $\begin{array}{l}\text { Geneva }^{a} \\
\text { Weiki }^{\mathrm{b}}\end{array}$ & $<0.001 *$ & Geneva-Weiki & 0.013 & -0.201 * \\
\hline Temperature & $\begin{array}{l}30{ }^{\circ} \mathrm{C}^{\mathrm{a}} \\
50^{\circ} \mathrm{C}^{\mathrm{b}}\end{array}$ & $<0.001$ * & $30^{\circ} \mathrm{C}-50^{\circ} \mathrm{C}$ & 0.013 & $-0.079 *$ \\
\hline Time & $\begin{array}{l}10 \min ^{\mathrm{a}} \\
30 \min ^{\mathrm{a}} \\
60 \min ^{\mathrm{b}} \\
180 \min ^{\mathrm{c}}\end{array}$ & $<0.001 *$ & $\begin{array}{l}10 \mathrm{~min}-60 \mathrm{~min} \\
10 \mathrm{~min}-30 \mathrm{~min} \\
10 \mathrm{~min}-180 \mathrm{~min} \\
60 \mathrm{~min}-30 \mathrm{~min} \\
60 \mathrm{~min}-180 \mathrm{~min} \\
30 \mathrm{~min}-180 \mathrm{~min}\end{array}$ & $\begin{array}{l}0.018 \\
0.018 \\
0.017 \\
0.018 \\
0.017 \\
0.017\end{array}$ & $\begin{array}{c}-0.056^{*} \\
-0.003 \\
-0.153^{*} \\
0.053^{*} \\
-0.097^{*} \\
-0.151^{*}\end{array}$ \\
\hline Osmotic solution & $\begin{array}{l}\text { Sucrose }^{\mathrm{a}} \\
\text { Maltitol }^{\mathrm{a}} \\
\text { Xylitol }^{\mathrm{b}}\end{array}$ & $<0.001$ * & $\begin{array}{l}\text { Xylitol-Maltitol } \\
\text { Xylitol-Sucrose } \\
\text { Maltitol-Sucrose }\end{array}$ & $\begin{array}{l}0.015 \\
0.015 \\
0.015\end{array}$ & $\begin{array}{l}0.046 * \\
0.045 * \\
-0.007\end{array}$ \\
\hline
\end{tabular}

Note: Means within columns, sharing the same superscript, are not significantly different from each other (Tukey's HSD, $p<0.05) .{ }^{*}$ denotes a statistically significant difference.

There were a few significant $(p<0.05)$ interactions between the tested variables (Table 2) for cultivar-solution and very strong interaction $(p<0.01)$ for cultivar-time, temperature-time, time-solution, cultivar-temperature-solution. In comparison to the other variables (WR and WL), SG interactions between variables were more often strongly influenced by osmotic solution.

The Peleg's mathematical model has shown its high usefulness for the SG prediction (Table 7). The $C R V$ values for $30{ }^{\circ} \mathrm{C}$ were often exceeding the critical value (20\%), but they gives high goodness of fit at $50{ }^{\circ} \mathrm{C}$ OD. In most cases, fitting values for $50{ }^{\circ} \mathrm{C}$ have provided high $R^{2}$ values, and low $C R V$, RMSE and $\chi^{2}$ values. The usefulness of this model was also confirmed by Arballo et al. [15] and Cichowska et al. [21]. No visible trend was established for the $K_{1}$ values of SG for the "Geneva" cultivar. For the "Weiki" cultivar, there was a noticeable reduction in the $\mathrm{K}_{1}$ value when the temperature was increased. The impact of the applied temperature on $K_{1}$ values was also reported by Ganjloo et al. [31]. This requires further analysis in future experiments. 
Table 7. Values of RMSE, $\chi^{2}, R^{2}$ and $C R V$ of best fitting mathematical model of SG.

\begin{tabular}{|c|c|c|c|c|c|c|c|c|c|c|}
\hline Cultivar & Temperature & Solution & Model & $K_{1}$ & $K_{2}$ & $K_{\mathrm{s}}$ & RMSE & $\chi^{2}$ & $C R V(\%)$ & $R^{2}$ \\
\hline \multirow{12}{*}{ Geneva } & \multirow{6}{*}{$30^{\circ} \mathrm{C}$} & \multirow{2}{*}{ sucrose } & Ade-Omowaye & - & - & 0.010 & 0.031 & 0.001 & 38.88 & 0.358 \\
\hline & & & Peleg & 8.164 & -0.001 & - & 0.018 & 0.000 & 22.76 & 0.780 \\
\hline & & \multirow{2}{*}{ maltitol } & Ade-Omowaye & - & - & 0.044 & 0.043 & 0.002 & 14.16 & 0.961 \\
\hline & & & Peleg & 1.021 & 0.024 & - & 0.038 & 0.001 & 12.54 & 0.969 \\
\hline & & \multirow{2}{*}{ xylitol } & Ade-Omowaye & - & - & 0.024 & 0.049 & 0.003 & 36.22 & 0.832 \\
\hline & & & Peleg & -2.186 & 0.055 & - & 0.034 & 0.001 & 24.63 & 0.922 \\
\hline & \multirow{6}{*}{$50^{\circ} \mathrm{C}$} & \multirow{2}{*}{ sucrose } & Ade-Omowaye & - & - & 0.023 & 0.023 & 0.001 & 16.42 & 0.940 \\
\hline & & & Peleg & 1.137 & 0.055 & - & 0.026 & 0.001 & 18.86 & 0.921 \\
\hline & & \multirow{2}{*}{ maltitol } & Ade-Omowaye & - & - & 0.022 & 0.027 & 0.001 & 19.37 & 0.873 \\
\hline & & & Peleg & 3.339 & 0.038 & - & 0.024 & 0.001 & 17.29 & 0.898 \\
\hline & & \multirow{2}{*}{ xylitol } & Ade-Omowaye & - & - & 0.029 & 0.043 & 0.002 & 23.76 & 0.872 \\
\hline & & & Peleg & 2.103 & 0.016 & - & 0.038 & 0.002 & 21.20 & 0.898 \\
\hline \multirow{12}{*}{ Weiki } & \multirow{6}{*}{$30^{\circ} \mathrm{C}$} & \multirow{2}{*}{ sucrose } & Ade-Omowaye & - & - & - & - & - & - & - \\
\hline & & & Peleg & 3.101 & 0.000 & - & 0.010 & 0.000 & 4.05 & 0.988 \\
\hline & & \multirow{2}{*}{ maltitol } & Ade-Omowaye & - & - & - & - & - & - & - \\
\hline & & & Peleg & 2.947 & 0.000 & - & 0.021 & 0.000 & 8.45 & 0.952 \\
\hline & & \multirow{2}{*}{ xylitol } & Ade-Omowaye & - & - & 0.036 & 0.093 & 0.010 & 37.56 & 0.208 \\
\hline & & & Peleg & 2.782 & 0.003 & - & 0.035 & 0.001 & 14.11 & 0.888 \\
\hline & \multirow{6}{*}{$50^{\circ} \mathrm{C}$} & \multirow{2}{*}{ sucrose } & Ade-Omowaye & - & - & 0.044 & 0.121 & 0.018 & 39.43 & 0.066 \\
\hline & & & Peleg & 2.266 & 0.002 & - & 0.029 & 0.001 & 9.63 & 0.944 \\
\hline & & \multirow{2}{*}{ maltitol } & Ade-Omowaye & - & - & 0.044 & 0.099 & 0.012 & 33.64 & 0.431 \\
\hline & & & Peleg & 2.244 & 0.012 & - & 0.051 & 0.003 & 17.36 & 0.848 \\
\hline & & \multirow{2}{*}{ xylitol } & Ade-Omowaye & - & - & 0.052 & 0.101 & 0.012 & 29.18 & 0.626 \\
\hline & & & Peleg & 1.871 & 0.032 & - & 0.078 & 0.007 & 22.59 & 0.776 \\
\hline
\end{tabular}

"-" denotes values which cannot be calculated using this prediction model.

\section{Materials and Methods}

\subsection{Sample Preparation}

The study was performed using two cultivars of kiwiberry: (Actinidia arguta) 'Geneva' and 'Weiki'. Plants grew on the commercial orchard under the supervision of the Environmental Protection Department, Warsaw University of Life Sciences (SGGW), Poland. Fruits were collected before reaching eating maturity stage (soft). The material was stored in darkness at $1{ }^{\circ} \mathrm{C}$ at a humidity of $90 \%$ until it was ripe. Before each experiment, kiwiberry fruits were removed from the storage and left to equilibrate to room temperature $\left(20 \pm 1^{\circ} \mathrm{C}\right)$, washed (with tap water) and dried. Ripe fruits were weighed, and the dry matter was determined according to AOAC 920.151 norm [35].

\subsection{Dehydration Procedure}

Before the dehydration process, fruits were cut in halves and weighed. Dehydration was performed using $60 \% w / w$ solutes of sucrose, xylitol and maltitol, respectively. The concentration of these solutes was established during preliminary experiments, and it was based on the results presented in the literature data $[18,26]$. The OD was executed in a precision hot water bath for $10 \mathrm{~min}, 30 \mathrm{~min}, 60 \mathrm{~min}$ and $180 \mathrm{~min}$, respectively, with an agitation speed of $1 \mathrm{~Hz}$ and water temperature at $30{ }^{\circ} \mathrm{C}$ and $50{ }^{\circ} \mathrm{C}\left( \pm 1{ }^{\circ} \mathrm{C}\right)$. For each experiment, $22 \mathrm{~g}( \pm 2.5 \mathrm{~g})$ of kiwiberry halves were put into $250 \mathrm{~mL}$ beakers containing $80 \mathrm{~mL}$ of osmotic solutions. After reaching the setup dehydration time, the material was removed from the bath, washed using $200 \mathrm{~g}$ distilled water, and gently placed on filtration paper to remove liquid residue. Samples were weighed and dry matter was determined. Each osmotic dehydration run was repeated twice. 


\subsection{Analytical Methods}

\subsubsection{Mathematical Modeling}

WR, WL and SG, which are the parameters describing osmotic dehydration process, were calculated according to the following equations:

$$
\begin{gathered}
W R=\frac{m_{0}-m_{\tau}}{m_{0}} \cdot 100 \% \\
W L=\frac{m_{0} \cdot\left(1-d \cdot m_{\cdot o}\right)-m_{\tau} \cdot(1-d \cdot m \cdot t)}{m_{0} \cdot d \cdot m \cdot 0} \\
S G=\frac{\left(m_{t} \cdot d \cdot m_{\cdot t}-m_{0} \cdot d \cdot m \cdot 0\right)}{m_{0} \cdot d \cdot m \cdot 0}
\end{gathered}
$$

To describe the kinetics of the OD, the following modified equations proposed by Ade-Omowaye et al. [25] and model proposed by Peleg [24] were employed to fit the experimental results.

WR, WL and SG data (Equations (1)-(3)) for the Ade-Omowaye et al. model were fitted as:

$$
\begin{aligned}
& W R=K_{m} \tau^{0.5} \\
& W L=K_{\omega} \tau^{0.5} \\
& S G=K_{s} \tau^{0.5}
\end{aligned}
$$

For the Peleg's model:

$$
Y=Y_{0} \pm \frac{\tau}{K_{1}+K_{2} \tau}
$$

Fitting of the mathematical functions was performed using Table Curve 2D v5.01 software (SYSTAT Software, Inc., Chicago, IL, USA). The coefficient of determination $\left(R^{2}\right)$ (Equation (11)), the reduced chi-squared statistic $\left(\chi^{2}\right)$ (Equation (9)), the root mean square error (RMSE) (Equation (8)), and the coefficient of residual variation $(C R V)$ (Equation (10)) were used to evaluate the goodness of fit of tested models:

$$
\begin{gathered}
\text { RMSE }=\sqrt{\frac{\sum_{i=1}^{N}\left(M R_{i, p}-M R_{i, e}\right)^{2}}{N}} \\
\chi^{2}=\frac{\sum_{i=1}^{N}\left(M R_{i, p}-M R_{i, e}\right)^{2}}{N-n} \\
C R V=100 \% \cdot \frac{\sqrt{\chi^{2}}}{Y} \\
R^{2}=\frac{\sum_{i=1}^{N}\left(M R_{i, p}-M R_{p}\right)^{2}}{\sum_{i=1}^{N}\left(M R_{i, e}-M R_{p}\right)^{2}}
\end{gathered}
$$

The high $R^{2}$ values and the low $\chi^{2}$ and $R M S E$ values indicate that the model fits well to the experimental data. The values of $C R V$ less than $20 \%$ indicate that the model can be used for predictions.

\subsubsection{Statistical Analysis}

The statistical software Statgraphics Plus version 18 (StatPoint), and Excel 2015 (Microsoft) were used for data analysis. The multifactorial analysis of variance (MANOVA) was performed with a significance level of $\alpha=0.05$. In the case of significant associations, post-hoc Tukey's test was performed. 


\section{Conclusions}

The maltitol, the xylitol and the sucrose are the effective osmotic agents for dehydration of kiwiberry. Both used polyols (xylitol, maltitol) can be considered as an effective and less-caloric alternative to the commonly used sucrose. For the tested concentration $(60 \%)$, the most effective solution was xylitol. For the OD process at $30^{\circ} \mathrm{C}$, the WR, WL and SG parameters were similar for maltitol and sucrose. The best fitting model for the mass transfer modelling was the Peleg's equation. Increased temperature resulted in an increased initial rate of mass transfer and improved overall effectiveness of the process.

Author Contributions: M.B. performed the experiments, as well as wrote the paper; A.W. designed the experiment and analyzed the data; P.L. provided material (fruit) for testing; E.G. was the supervisor who contributed analysis tools and corrected the manuscript.

Conflicts of Interest: The authors declare no conflicts of interest

\section{Nomenclature}

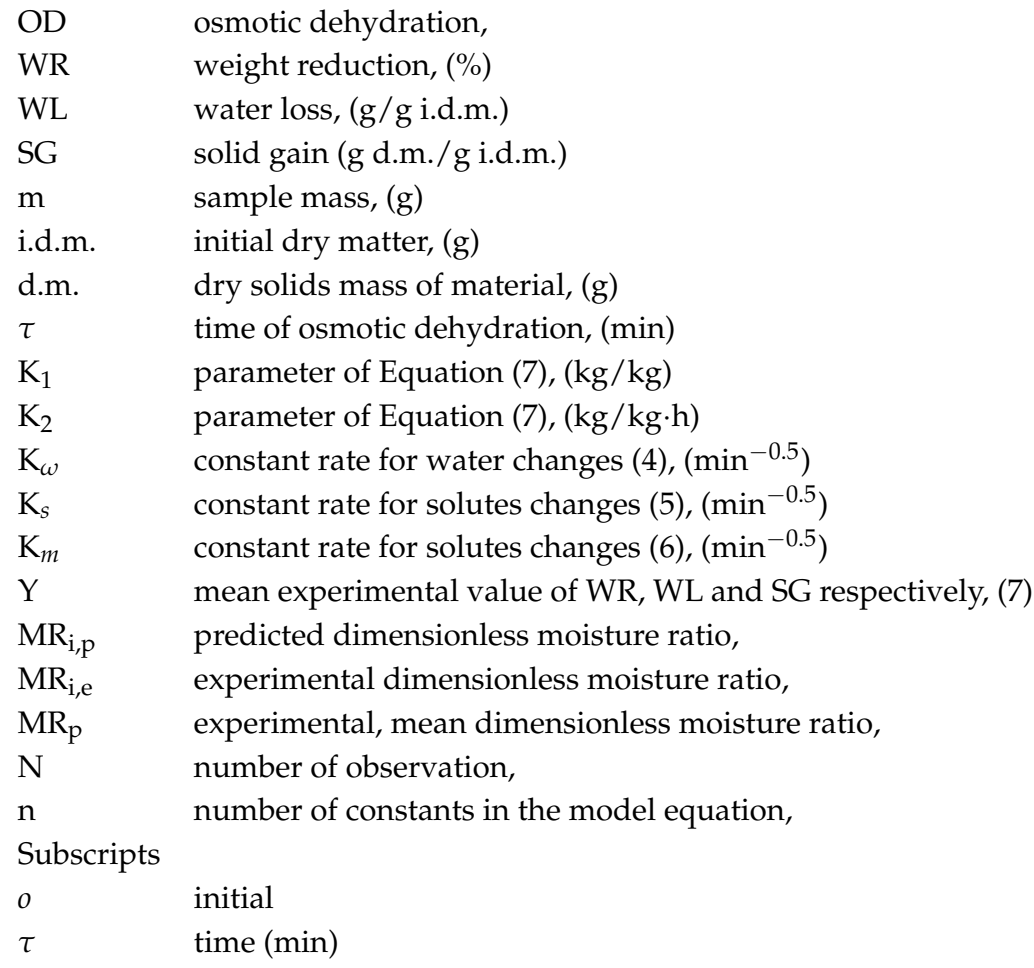

\section{References}

1. Yadav, A.K.; Singh, S.V. Osmotic dehydration of fruits and vegetables: A review. J. Food Sci. Technol. 2014, 51, 1654-1673. [CrossRef] [PubMed]

2. Chwastek, A. Methods to increase the rate of mass transfer during osmotic dehydration of foods. Acta Sci. Pol. Technol. Aliment. 2014, 13, 341-350. [CrossRef] [PubMed]

3. Kowalski, S.J.; Mierzwa, D. Influence of Osmotic Pretreatment on Kinetics of Convective Drying and Quality of Apples. Dry. Technol. 2013, 31, 1849-1855. [CrossRef]

4. Castelló, M.L.; Igual, M.; Fito, P.J.; Chiralt, A. Influence of osmotic dehydration on texture, respiration and microbial stability of apple slices (Var. Granny Smith). J. Food Eng. 2009, 91, 1-9. [CrossRef]

5. Nuñez-Mancilla, Y.; Perez-Won, M.; Vega-Gálvez, A.; Arias, V.; Tabilo-Munizaga, G.; Briones-Labarca, V.; Lemus-Mondaca, R.; Di Scala, K. Modeling mass transfer during osmotic dehydration of strawberries under high hydrostatic pressure conditions. Innov. Food Sci. Emerg. Technol. 2011, 12, 338-343. [CrossRef]

6. Held, C.; Sadowski, G. Compatible solutes: Thermodynamic properties relevant for effective protection against osmotic stress. Fluid Phase Equilib. 2016, 407, 224-235. [CrossRef] 
7. Held, C.; Neuhaus, T.; Sadowski, G. Compatible solutes: Thermodynamic properties and biological impact of ectoines and prolines. Biophys. Chem. 2010, 152, 28-39. [CrossRef] [PubMed]

8. Rastogi, N.; Raghavarao, K.S.M. Mass transfer during osmotic dehydration of pineapple: Considering Fickian diffusion in cubical configuration. LWT Food Sci. Technol. 2004, 37, 43-47. [CrossRef]

9. Megías-Pérez, R.; Gamboa-Santos, J.; Soria, A.C.; Villamiel, M.; Montilla, A. Survey of quality indicators in commercial dehydrated fruits. Food Chem. 2014, 150, 41-48. [CrossRef] [PubMed]

10. United States Department of Agriculture Food Composition Databases Show Foods—Cranberries, Dried, Sweetened (Includes Foods for USDA's Food Distribution Program). Available online: https://ndb.nal.usda. gov/ndb/foods/show/301093 (accessed on 14 April 2018).

11. Mendonça, K.S.; de Jesus, J.R.; Pereira, M.C.A.; Corrêa, J.L.G. Osmotic Dehydration of Yacon Slices: Effect of Different Polyols on Mass Transfer Parameters; Editora Edgard Blücher: São Paulo, Brazil, 2015; pp. 5069-5076.

12. Venkatachalapathy, K.; Raghavan, G.S.V. Microwave Drying of Osmotically Dehydrated Blueberries. J. Microw. Power Electromagn. Energy 1998, 33, 95-102. [CrossRef]

13. Bialik, M.; Gondek, E.; Wiktor, A.; Latocha, P.; Witrowa-Rajchert, D. Mathematical Modeling of Actinidia arguta (Kiwiberry) Drying Kinetics. Agric. Eng. 2017, 21. [CrossRef]

14. Latocha, P. The Nutritional and Health Benefits of Kiwiberry (Actinidia arguta)—A Review. Plant Foods Hum. Nutr. 2017, 72, 325-334. [CrossRef] [PubMed]

15. Latocha, P.; Łata, B.; Stasiak, A. Phenolics, ascorbate and the antioxidant potential of kiwiberry vs. common kiwifruit: The effect of cultivar and tissue type. J. Funct. Foods 2015, 19, 155-163. [CrossRef]

16. Rodrigues, S.; Fernandes, F.A.N. Ultrasound in food processing. In New Food Engineering Research Trends; Urwaye, A.P., Ed.; Nova Science Publishers: New York, NY, USA, 2008; pp. 103-135. ISBN 978-1-60021-897-2.

17. Tiroutchelvame, D.; Sivakumar, V.; Maran, P. Mass transfer kinetics during osmotic dehydration of amla (Emblica officinalis L.) cubes in sugar solution. Chem. Ind. Chem. Eng. Q. 2015, 21, 547-559. [CrossRef]

18. Arballo, J.R.; Bambicha, R.R.; Campañone, L.A.; Agnelli, M.E.; Mascheroni, R.H. Mass transfer kinetics and regressional-desirability optimisation during osmotic dehydration of pumpkin, kiwi and pear: Kinetics/ optimisation OD-pumpkin, kiwi, pear. Int. J. Food Sci. Technol. 2012, 47, 306-314. [CrossRef]

19. Alam, M.S.; Amarjit, S.; Sawhney, B.K. Response surface optimization of osmotic dehydration process for aonla slices. J. Food Sci. Technol. 2010, 47, 47-54. [CrossRef] [PubMed]

20. Yadav, B.S.; Yadav, R.B.; Jatain, M. Optimization of osmotic dehydration conditions of peach slices in sucrose solution using response surface methodology. J. Food Sci. Technol. 2012, 49, 547-555. [CrossRef] [PubMed]

21. Cichowska, J.; Żubernik, J.; Czyżewski, J.; Kowalska, H.; Witrowa-Rajchert, D. Efficiency of Osmotic Dehydration of Apples in Polyols Solutions. Molecules 2018, 23, 446. [CrossRef] [PubMed]

22. Koocheki, A.; Azarpazhooh, E. Evaluation of Mass Exchange during Osmotic Dehydration of Plum Using Response Surface Methodology. Int. J. Food Prop. 2010, 13, 155-166. [CrossRef]

23. Cao, H.; Zhang, M.; Mujumdar, A.S.; Du, W.; Sun, J. Optimization of Osmotic Dehydration of Kiwifruit. Dry. Technol. 2006, 24, 89-94. [CrossRef]

24. Peleg, M. An Empirical Model for the Description of Moisture Sorption Curves. J. Food Sci. 1988, 53, 1216-1217. [CrossRef]

25. Ade-Omowaye, B.I.O.; Rastogi, N.K.; Angersbach, A.; Knorr, D. Combined effects of pulsed electric field pre-treatment and partial osmotic dehydration on air drying behaviour of red bell pepper. J. Food Eng. 2003, 60, 89-98. [CrossRef]

26. Wiktor, A.; Śledź, M.; Nowacka, M.; Chudoba, T.; Witrowa-Rajchert, D. Pulsed Electric Field Pretreatment for Osmotic Dehydration of Apple Tissue: Experimental and Mathematical Modeling Studies. Dry. Technol. 2014, 32, 408-417. [CrossRef]

27. Torreggiani, D. Osmotic dehydration in fruit and vegetable processing. Food Res. Int. 1993, 26, 59-68. [CrossRef]

28. Assis, F.R.; Morais, R.M.S.C.; Morais, A.M.M.B. Mass Transfer in Osmotic Dehydration of Food Products: Comparison between Mathematical Models. Food Eng. Rev. 2016, 8, 116-133. [CrossRef]

29. Panagiotou, N.M.; Karathanos, V.T.; Maroulis, Z.B. Mass transfer modelling of the osmotic dehydration of some fruits: Osmotic dehydration of fruits. Int. J. Food Sci. Technol. 1998, 33, 267-284. [CrossRef]

30. Ciurzyńska, A.; Cichowska, J.; Kowalska, H.; Czajkowska, K.; Lenart, A. Osmotic dehydration of Braeburn variety apples in the production of sustainable food products. Int. Agrophys. 2018, 32, 141-146. [CrossRef] 
31. Ganjloo, A.; Rahman, R.A.; Bakar, J.; Osman, A.; Bimakr, M. Kinetics Modeling of Mass Transfer Using Peleg's Equation During Osmotic Dehydration of Seedless Guava (Psidium guajava L.): Effect of Process Parameters. Food Bioprocess Technol. 2012, 5, 2151-2159. [CrossRef]

32. Chiu, M.-T.; Tham, H.J.; Lee, J.-S. Optimization of osmotic dehydration of Terung Asam (Solanum lasiocarpum Dunal). J. Food Sci. Technol. 2017, 54, 3327-3337. [CrossRef] [PubMed]

33. Lee, J.-S.; Tham, H.J.; Wong, C.S. Osmotic dehydration of Kappaphycus alvarezii. J. Appl. Phycol. 2014, 26, 1063-1070. [CrossRef]

34. Lazarides, H.N.; Katsanidis, E.; Nickolaidis, A. Mass transfer kinetics during osmotic preconcentration aiming at minimal solid uptake. J. Food Eng. 1995, 25, 151-166. [CrossRef]

35. Official Methods of Analysis of AOAC International, 20th ed.; Latimer, G.W., AOAC International, Eds.; AOAC International: Gaithersburg, MD, USA, 2016; ISBN 978-0-935584-87-5.

Sample Availability: Samples of the compounds from the polyols (xylitol, maltitol) are available from the authors.

(C) 2018 by the authors. Licensee MDPI, Basel, Switzerland. This article is an open access article distributed under the terms and conditions of the Creative Commons Attribution (CC BY) license (http://creativecommons.org/licenses/by/4.0/). 